\title{
Prostaglandin F2-alpha receptor (FPr) expression on porcine corpus luteum microvascular endothelial cells (pCL-MVECs) Augusta Zannoni*1, Chiara Bernardini ${ }^{1}$, Tommaso Rada ${ }^{2}$, Luciana A Ribeiro $^{1}$, Monica Forni ${ }^{1}$ and Maria L Bacci ${ }^{1}$
}

Address: ${ }^{1}$ Department of Veterinary Morphophysiology and Animal Production, DIMORFIPA, Ozzano Emilia 40064, University of Bologna, Italy and ${ }^{2}$ Department of Polymer Engineering, University of Minho 4710-057 Braga, Portugal

Email: Augusta Zannoni* - augusta.zannoni@unibo.it; Chiara Bernardini - chiara.bernardini5@unibo.it;

Tommaso Rada - trada@dep.uminho.pt; Luciana A Ribeiro - laribeir@libero.it; Monica Forni - monica.forni@unibo.it; Maria L Bacci - marialaura.bacci@unibo.it

* Corresponding author

Published: 20 July 2007

Reproductive Biology and Endocrinology 2007, 5:31 doi:10.1 I86/|477-7827-5-31

This article is available from: http://www.rbej.com/content/5/I/3 I

(c) 2007 Zannoni et al; licensee BioMed Central Ltd.

This is an Open Access article distributed under the terms of the Creative Commons Attribution License (http://creativecommons.org/licenses/by/2.0), which permits unrestricted use, distribution, and reproduction in any medium, provided the original work is properly cited.

\begin{abstract}
Background: The corpus luteum $(\mathrm{CL})$ is a transient endocrine gland and prostaglandin $\mathrm{F} 2$-alpha is considered to be the principal luteolysin in pigs. In this species, the in vivo administration of prostaglandin F2-alpha induces apoptosis in large vessels as early as 6 hours after administration. The presence of the prostaglandin F2-alpha receptor (FPr) on the microvascular endothelial cells ( $\mathrm{PCL}-\mathrm{MVEC}$ ) of the porcine corpus luteum has not yet been defined. The aim of the study was to assess FPr expression in PCL-MVECs in the early and mid-luteal phases (EL$\mathrm{p}, \mathrm{ML}-\mathrm{p})$, and during pregnancy (P-p). Moreover, the effectiveness of prostaglandin F2-alpha treatment in inducing PCL-MVEC apoptosis was tested.
\end{abstract}

Methods: Porcine CLs were collected in the EL and ML phases and during P-p. All CLs from each animal were minced together and the homogenates underwent enzymatic digestion. The PCL-MVECs were then positively selected by an immunomagnetic separation protocol using Dynabeads coated with anti-CD3I monoclonal antibody and seeded in flasks in the presence of EGM 2-MV (Microvascular Endothelial Cell Medium-2). After 4 days of culture, the cells underwent additional immunomagnetic selection and were seeded in flasks until the confluent stage.

PCR Real time, western blot and immunodetection assays were utilized to assess the presence of FPr on PCLMVEC primary cultures. Furthermore, the influence of culture time (freshly isolated, cultured overnight and at confluence) and hormonal treatment (P4 and E2) on FPr expression in PCL-MVECs was also investigated. Apoptosis was detected by TUNEL assay of PCL-MVECs exposed to prostaglandin F2-alpha.

Results: We obtained primary cultures of $\mathrm{pCL}-\mathrm{MVEC}$ s from all animals. FPr mRNA and protein levels showed the highest value (ANOVA) in CL-MVECs derived from the early-luteal phase. Moreover, freshly isolated MVECs showed a higher FPr mRNA value than those cultured overnight and confluent cells (ANOVA). prostaglandin F2alpha treatment failed to induce an apoptotic response in all the PCL-MVEC cultures.

Conclusion: Our data showing the presence of FPr on MVECs and the inability of prostaglandin F2-alpha to evoke an in vitro apoptotic response suggest that other molecules or mechanisms must be considered in order to explain the in vivo direct pro-apoptotic effect of prostaglandin F2-alpha at the endothelial level. 


\section{Background}

The corpus luteum (CL) is a transient endocrine gland essential for the regulation of ovarian cycles as well as for establishing and maintaining pregnancy. Prostaglandin $\mathrm{F}_{2 \alpha}\left(\mathrm{PGF}_{2 \alpha}\right)$ is considered the principal luteolysin in domestic animals and acts on target cells [1] by means of a specific plasma membrane-associate receptor, prostaglandin F2-alpha receptor (FPr). The FPr was detected on steroidogenic luteal cells [2-5] but its presence on other target cells could not be excluded.

Our previous data [6] showed that, in a porcine CL regression model, cloprostenol (a $\mathrm{PGF}_{2 \alpha}$ synthetic analogue) first induces apoptosis of luteal endothelial cells then apoptosis of steroidogenic cells and suggest that the structural regression of the CL may begin with an early response of the endothelial compartment to $\mathrm{PGF}_{2 \alpha}$. This hypothesis relies on the assumption that FPrs are present on endothelial cells (ECs). The expression of the FPr was described by RT-PCR in bovine ECs derived from CLs [7]; on the contrary, FPr mRNA has been identified only on swine steroidogenic cells by an in situ study [8]. Therefore, to date, the presence of the FPr on luteal ECs is not fully clarified, perhaps due to the different techniques utilized.

The porcine CL is not sensitive to the luteolytic stimulus until day 12 of the cycle [9-11]. Luteal PGF $_{2 \alpha}$ binding sites increase during $\mathrm{CL}$ formation reaching a maximum on day 13 of the oestrous cycle, concurrently with the onset of luteal sensitivity to $\mathrm{PGF}_{2 \alpha}[3,12]$. Limited data exist confirming that an FPr increase is responsible for the acquisition of luteolytic sensitivity.

The importance of the interaction between luteal cells and ECs was demonstrated both in in vivo and in vitro experiments in bovine and swine species [13-17].

The interest in EC biology increased in parallel with the optimization of successful protocols for their isolation and culture, allowing the study of EC involvement in many different physiological or pathological processes. EC isolated from large vessels or from tissue microvasculature show a morphological heterogeneity $[18,19]$ and significant functional differences [20]. Additional differences have been observed among EC isolated from microvessels of different organs $[21,22]$ as well as from different regions of the same organ [23-25]. These differences are mainly due to the local micro-environment (e.g., the presence of matrix proteins, soluble cytokines, growth factors and paracrine signals) and to cell-to-cell communication.

In this context, the isolation and characterization of pCLMVECs may lead to a better insight into endocrine gland physiology and contribute to explaining some physiological differences during the CL lifespan.
Many studies have been focused on the CL-MVEC isolation in different species [23,26-31] except swine where MVEC isolation has been described only in the fetal organs [32] and the heart [33].

In order to obtain pure MVEC cultures from CLs at different stages (early and mid-luteal phases and during pregnancy), the initial aim of the present study was to define a reliable isolation method. Thus, our subsequent aims were to investigate the presence of the FPr, both at the mRNA and the protein level, on PCL-MVEC and to verify if $\mathrm{PGF}_{2 \alpha}$ treatment is effective in inducing pCL-MVEC apoptosis.

\section{Materials and methods pCL-MVEC culture set-up}

Animals and corpora lutea collection

Twelve prepubertal Large White gilts $(94 \pm 1.47 \mathrm{Kg}$ body weight) were injected i.m. with 1250 iu (international units) of equine chorionic gonadotropin (eCG; FolligonIntervet, Holland) and, $60 \mathrm{~h}$ later, with 750 iu of human chorionic gonadotropin (hCG; Corulon-Intervet) to synchronize ovulation. The animals were randomly assigned to three groups $(\mathrm{n} .=4)$. Four animals were artificially inseminated at $40 / 44 \mathrm{~h}$ post-hCG treatment and pregnancy was determined after 30 days by ultrasonography. The ovaries were surgically removed from all animals: 4 at the early luteal phase (EL-p: 6 days after ovulation), 4 at the mid-luteal phase (ML-p: 12 days after ovulation) and 4 during the pregnancy phase (P-p: 60 days of pregnancy).

All animals were housed and used according to EEC animal care guidelines. The experimental procedures had previously been submitted to and approved by the Ethical Committee of Bologna University.

\section{Isolation and culture conditions of Microvascular Endothelial Cells (MVECs)}

The ovaries were immediately taken to the laboratory in ice-cold DPBS (Dulbecco Phosphate Buffer Saline; Cambrex Bio Sciences, Verviers, Belgium) and washed several times in sterile DPBS; the corpora lutea (CLs) were then isolated under sterile conditions.

All CLs from each animal $(14.1 \pm 5.9)$ were cut into small fragments $\left(\sim 1 \mathrm{~mm}^{3}\right)$ with a razor blade and minced together with a pestle and mortar. Small aliquots $(100 \mu \mathrm{g})$ of homogenate were immediately frozen in liquid nitrogen for RNA extraction, and protein and progesterone $\left(\mathrm{P}_{4}\right)$ analyses. The remaining homogenate was washed (3 times) by adding sterile DPBS (1:3, w:v) and centrifuged $(500 \times \mathrm{g}, 5 \mathrm{~min})$. The final pellet was resuspended in sterile DPBS containing collagenase ( $2 \mathrm{mg} / \mathrm{ml}$; type IA [ 420 U/mg]; Sigma Chemical Company, St. Louis, MO, USA), BSA ( $4 \mathrm{mg} / \mathrm{ml}$; Fraction V, Sigma) and DNase I (0.02 mg/ 
$\mathrm{ml} ;$ [1.87 U/mg]; Sigma). After $20 \mathrm{~min}$ on a rocking platform $(200 \mathrm{rpm})$ at $37^{\circ} \mathrm{C}$, enzymatic digestion was stopped by adding FBS (Foetal Bovine Serum, Gibco-Invitrogen, Paisley, UK) $(1: 1, v / v)$; the suspension was filtered (pore sizes: $280 \mu \mathrm{m}$; Sigma) and placed on ice, then centrifuged $(800 \times \mathrm{g}, 20 \mathrm{~min})$ and resuspended in DPBSBSA $(0.1 \% ; \mathrm{w} / \mathrm{v})$ at a final concentration of $5 \times 10^{5}$ cells/ $\mathrm{ml}$ (Thoma chamber counting). The pCL-MVECs were then positively selected by an immunomagnetic separation protocol using Dynabeads ${ }^{\varpi}$ coated with anti-CD31 monoclonal antibody (Invitrogen), according to the manufacturer's instructions. Briefly, the cells were mixed with Dynabeads $^{\circledast}$ to give a ratio of $5 \times 10^{5}$ cells $/ 4 \times 10^{8}$ beads/ $\mathrm{ml}$ and were then incubated for $20 \mathrm{~min}$ at $4{ }^{\circ} \mathrm{C}$ on a rocking platform.

After incubation, the suspension was diluted $(1: 3, \mathrm{v} / \mathrm{v})$ with DPBS-BSA $(0.1 \%)$, endothelial cells were then exposed to Magnetic Particle Concentrators (DYNAL MPC ${ }^{\oplus}$, Invitrogen) for $2 \mathrm{~min}$ and washed five times in DPBS-BSA.

The last resuspension was carried out in $\mathrm{EGM}^{\mathrm{TM}} 2-\mathrm{MV}$ medium (Microvascular Endothelial Cell Medium-2, Cambrex); cell viability was determined using the Trypan Blue exclusion test and viable cell density was calculated using a Thoma chamber.

The pCL-MVECs $\left(3 \times 10^{5}\right.$ viable cells/flask) were then placed in a T-25 tissue culture flask (Falcon, BecktonDickinson, Franklin Lakes NJ, USA) in $\mathrm{EGM}^{\mathrm{TM}} 2-\mathrm{MV}$ supplemented with BulletKit ${ }^{\circledast}$ (Cambrex) in an humidified atmosphere at $5 \% \mathrm{CO}_{2}\left(38.5^{\circ} \mathrm{C}\right)$. After 4 days of culture, the cells were trypsinized (Trypsin-EDTA solution, Sigma) for 6 min at $37^{\circ} \mathrm{C}$, further selected with Dynabeads ${ }^{\circledast}$ and seeded again in $\mathrm{EGM}^{\mathrm{TM}} 2-\mathrm{MV}$ supplemented with Bullet$\mathrm{Kit}^{\oplus}$. At the $5^{\text {th }}$ day of culture, the medium was substituted by Human Endothelial-SFM (HE-SFM; Gibco-Invitrogen) supplemented with 15\% FBS (Gibco-Invitrogen) and 1\% antibiotic/antimicotic solution (Gibco-Invitrogen); the medium was changed every $24 \mathrm{~h}$ until confluence. The cultures were observed daily using phase-contrast inverted microscopy (Nikon Eclipse TS100).

In addition, freshly isolated (dispersed) and overnight (ON) cultured of ML-p pCL-MVECs were recovered; in order to test the microenvironmental effects of steroid hormones, the ML-p pCL-MVECs were cultured in complete HE-SFM medium with and without hormones $\left(\mathrm{P}_{4}\right.$,

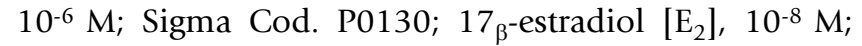
Sigma Cod. E8875) until confluence.

Confluent cultures of porcine Aorthic Endothelial Cells (pAEC) $\left(8^{\text {th }}\right.$ passage) were assessed [34] at the same time.

\section{Progesterone assay}

Tissue $\mathrm{P}_{4}$ levels were determined as previously described by Ribeiro et al. [35]. A small amount of frozen CL homogenate (for each animal) was further homogenised by Ultra Turrax in PBS $(0.1 \mathrm{~g} / \mathrm{ml})$ in an ice bath. An aliquot $(20 \mu \mathrm{l})$ was extracted with petroleum ether $(1 \mathrm{~h}$ at RT on a rotary shaker) and centrifuged. The ether was then collected and dried under a $\mathrm{N}_{2}$ stream. The dried ether extract was resuspended in PBS $(1 \mathrm{ml})$, diluted 1:50 and an aliquot of $50 \mu \mathrm{l}$ was then assayed using a validated Radio Immuno Assay (RIA) [36]. The $\mathrm{P}_{4}$ results are expressed as ng/mg tissue. The intra- and inter-assay coefficients of variation were $5.2 \%$ and $9 \%$, respectively.

\section{Characterization of PCL-MVEC cultures}

Cells were grown in slide chambers (8 well Culture Slide, Falcon $^{\mathrm{TM}}$, Becton-Dickinson) for $24 \mathrm{~h}$ and immunostained for endothelial cell markers (factor VIII, CD31). The slides were fixed with ethanol/acetic acid $(2: 1)$, washed with PBS three times and blocked with 10\% (v/v) FBS in PBS for $1 \mathrm{~h}$ at RT. Primary antibodies, 1:200 rabbit antihuman Factor VIII (A0082, Dako A/S, Glostrup, Denmark) or 1:100 mouse anti-porcine CD31 (MCA1746, Serotec LTD, Oxford, UK), were added for $1 \mathrm{~h}$ at RT; then, after several washings with PBS, secondary fluorescein isothiocyanate (FITC)-conjugated antibodies were added (1:800 in DPBS). Negative controls without primary antibodies were performed.

The cells were counterstained with propidium iodide (PI) and examined under an epifluorescence microscope (Eclipse E600, Nikon, Japan) with fluorescein (FITC) and tetramethylrhodamine (TRITC) filters using a Nikon digital camera. A minimum of 100 cells was evaluated in each experimental sample.

To evaluate the presence of contaminant steroidogenic luteal cells, a PCR Real time amplification for Steroidogenic acute regulatory protein (StAR) [37] was conducted on pCL-MVEC cultures, as described below.

\section{Identification of FPr}

RNA extraction and Real time PCR

Total RNA was extracted from endothelial cells (pCLMVECs and pAECs) using RNeasy Mini Kits 50 (Qiagen Sciences Inc, MD, USA) and was treated with an RNasefree DNase set (Qiagen) according to the manufacturer's instruction. Total RNA was extracted from tissue CL homogenates using a TRIZOL isolation reagent (Invitrogen) according to the manufacturer's instructions.

Purified RNAs were resuspended in $25 \mu \mathrm{l}$ of RNAse-free water and spectrophotometrically quantified (A260 nm); their quality was checked by gel electrophoresis on $2 \%$ agarose gel. One microgram of total RNA was reverse-tran- 
scribed to cDNA using an iScript cDNA Synthesis Kit (BioRAD Laboratories Inc., California, USA) for a final volume of $20 \mu \mathrm{l}$. Transcription reactions without reverse transcriptase were performed in order to check for possible DNA contamination.

Swine primers (FPr, StAR, HPRT [Hypoxanthine phosphoribosyltransferase]) were designed to span one intron, to avoid genomic DNA amplification, using Beacon Designer 2.07 Software (Premier Biosoft International, Palo Alto, CA, USA). Primer sequences, expected PCR product lengths and sequence accession numbers are shown in Table 1.

Real-time quantitative PCRs were performed in the iCycler Thermal Cycler (Bio-RAD) using SYBR green I detection. A master-mix of the following reaction components was prepared to indicate end-concentrations: $0.5 \mu \mathrm{l}$ forward primer $(0.2 \mu \mathrm{M}), 0.5 \mu \mathrm{l}$ reverse primer $(0.2 \mu \mathrm{M}), 9 \mu \mathrm{l}$ water and 12.5 $\mu \mathrm{l}$ IQ SYBR Green BioRad Supermix (BioRAD Laboratories Inc.). cDNA $(2.5 \mu \mathrm{l})$ was added to the master mix $(22.5 \mu \mathrm{l})$. All samples were assayed in duplicate. The real-time PCR protocol employed was the following: initial denaturation for $3 \mathrm{~min}$ at $95^{\circ} \mathrm{C}, 40$ cycles at $95^{\circ} \mathrm{C}$ for $15 \mathrm{sec}$ and $60^{\circ} \mathrm{C}$ for $30 \mathrm{sec}$, followed by a melting step from $55^{\circ}$ to $95^{\circ} \mathrm{C}$ with a rate of $0.5^{\circ} \mathrm{C} / \mathrm{s}$. The housekeeping gene HPRT data were used to normalize the RNA amount in all samples.

Real-time efficiency for each primer set was acquired by amplification of a standardized cDNA dilution series. The specificity of the amplified PCR products was verified by melting curve analyses and an agarose gel electrophoresis run. The housekeeping gene HPRT was used to normalize the amount of RNA. FPr mRNA expression was calculated as $\Delta \mathrm{C}_{\mathrm{T}}\left(\mathrm{HPRT} \mathrm{C}_{\mathrm{T}}-\mathrm{FPr} \mathrm{C}_{\mathrm{T}}\right.$ ) [38] for all samples.

\section{Protein extraction and Western Blot}

The protein contents of CL homogenates and endothelial cell lysates (sonication in PBS, $1 \times 10^{6}$ cells/200 $\mu$ l) were determined by a protein assay kit (Sigma). Protein aliquots $(20 \mu \mathrm{g})$ were separated on NuPage $10 \%$ Bis-Tris Gel (Invitrogen) for $50 \mathrm{~min}$ at $200 \mathrm{~V}$ and were then electrophoretically transferred onto a nitrocellulose membrane. The blots were washed in PBS, and protein transfer was checked by staining the nitrocellulose membranes with
$0.2 \%(\mathrm{w} / \mathrm{v})$ Ponceau Red and gels with Comassie Blue. Non-specific protein binding on the nitrocellulose membrane was blocked with $5 \%(\mathrm{w} / \mathrm{v})$ milk powder in PBST20 (phosphate buffer saline - $0.1 \%(\mathrm{v} / \mathrm{v})$ Tween-20) for $1 \mathrm{~h}$ at RT. The membranes were then incubated with a 1:500 dilution of a rabbit anti-FPr (NLS 1049, Novus Biologicals Inc, Littleton, CO, USA) in TBS-T20 (20 mM Tris$\mathrm{HCl}, \mathrm{pH} 7.4 ; 500 \mathrm{mM} \mathrm{NaCl} ; 0.1 \%$ Tween-20) with $0.5 \%$ milk overnight $(\mathrm{O} / \mathrm{N})$ at $4{ }^{\circ} \mathrm{C}$. After several washings with PBS-T20, the membranes were incubated with the secondary biotin-conjugated antibody (1:80 000) and then with a 1:1000 dilution of an anti-biotin horseradish peroxidase (HRP)-linked antibody. Western blots were developed using a chemiluminescent substrate (Pierce Biotechnology Inc, Rockford, IL, USA) according to the manufacturer's instructions. The membranes were stripped and reprobed by rabbit anti-HPRT (1:250; FL218, Santa Cruz Biotechnology Inc, Santa Cruz CA, USA) in order to normalize the results. The relative protein content was determined by the density of the resultant bands and expressed in arbitrary units (AU) relative to the HPRT content, using Quantity One Software (Bio-Rad).

\section{Immunofluorescent staining}

The immunolocalization of the FPr in pCL-MVEC and pAEC cultures was performed by indirect immunofluorescence. Cells grown in slide chambers for $24 \mathrm{~h}$ were fixed with acetone and methanol $(1: 1 ; \mathrm{v} / \mathrm{v})$ for $10 \mathrm{~min}$ at $-20^{\circ} \mathrm{C}$ and washed several times with PBS. To better identify the FPr at the plasma membrane level, immunofluorescent staining was also performed without previous sample fixation. Slides were blocked with $10 \%$ FBS in PBS for $1 \mathrm{~h}$ at RT and incubated $\mathrm{O} / \mathrm{N}$ at $4^{\circ} \mathrm{C}$ with anti-FPr diluted $1: 100$ in $10 \%$ FBS in PBS or without a primary antibody (negative control). After several washings in PBS, an FITC-conjugated secondary antibody was added (1:800 at RT for 1 h).

The cells were then counterstained with PI and examined under an epifluorescence microscope equipped with appropriate filters. A minimum of 100 cells were evaluated for each experimental sample.

\section{PGF $_{2 \alpha}$ treatment of pCL-MVECs}

pCL-MVECs were grown to confluence (70-80\%) in 8 well slide chambers in HE-SFM (15\% FBS) and then

Table I: Forward and reverse primer sequences, RT-PCR product length and accession number (Acc.No.) in the EMBL database.

\begin{tabular}{|c|c|c|c|}
\hline Primer & Sequence $\left(5^{\prime}-3^{\prime}\right)$ & Product Length (bp) & Acc. No. \\
\hline $\mathrm{FPr}$ & $\begin{array}{l}\text { For.: TCAGCAGCACAGACAAGG } \\
\text { Rev.: TTCACAGGCATCCAGATAATC }\end{array}$ & $|5|$ & AY043485 \\
\hline StAR & $\begin{array}{l}\text { For.: GGACATCCTCAGCAACCAG } \\
\text { Rev.: GTCCACCACCACCTCCAG }\end{array}$ & $12 \mid$ & $\underline{\text { U53020 }}$ \\
\hline HPRT & $\begin{array}{l}\text { For.: GGACAGGACTGAACGGCTTG } \\
\text { Rev.: GTAATCCAGCAGGTCAGCAAAG }\end{array}$ & 115 & AFI43818 \\
\hline
\end{tabular}


exposed to $10 \mu \mathrm{g} / \mathrm{ml} \mathrm{PGF}_{2 \alpha}$ (P5069; Sigma) in HE-SFM (1 $\%$ FBS) for 6,12 , and 24 hours. pAEC cultures were also treated with PGF $_{2 \alpha}$ as well as with LPS $(10 \mu \mathrm{g} / \mathrm{mL}$ for $24 \mathrm{~h}$; E. coli 055:B5, Sigma) as positive controls. Apoptosis was determined by the ApopTag Fluorescein in situ apoptosis detection Kit (S7110, Intergen Company, 10577 NY, USA), according to the manufacturer's instructions. The cells were fixed in 1\% paraformaldehyde in PBS, postfixed in precooled ethanol:acetic acid $(2: 1, \mathrm{v}: \mathrm{v})$, then incubated with dTT enzyme for digoxigenin dNTP incorporation (30 $\mathrm{min}$ at $37^{\circ} \mathrm{C}$ ) and, after several washings with DPBS, finally incubated with anti-digoxigenin-fluorescein antibody (30 min at RT in the dark). The cells were counterstained with PI and observed under an epifluorescence microscope. A minimum of 200 cells were evaluated for each experimental point.

\section{Statistical analysis}

Data were analyzed by one-way analysis of variance (ANOVA); the significant differences were analyzed by the Duncan's test (SPSS Inc, Chicago, IL, USA). A probability of $\mathrm{P}<0.05$ was considered significant. Data represent mean $\pm \operatorname{SD}(n=4)$.

\section{Results}

\section{Assessment of pCL-MVEC cultures}

The functional stages of isolated corpora lutea were confirmed by tissue $\mathrm{P}_{4}$ concentrations $(26.78 \pm 4.2$, $48.62 \pm$ 4.1 and $90.43 \pm 1.81 \mathrm{ng} / \mathrm{mg}$ at EL-, ML- and P-phases, respectively).

We were able to obtain primary cultures of pCL-MVECs from all animals. The primary cultures reached confluence (about $10^{6}$ cells/flask) in $7.6 \pm 2.7$ days (min 4, max 12); all cultures derived from EL-p CLs reached confluence faster ( $5 \pm 1$ days) than ML-p- and P-p-MVECs.

pCL-MVEC cultures showed the typical heterogeneous morphologies already described for bovine CL-MVEC $[23,39]$. Cobble-stone shaped, polygonal opaque, spindle-shaped and phase-dense MVEC phenotypes were observed (Fig. 1A, B). No evidence of contaminating cells was observed

\section{Characterization of $\mathrm{pCL}-\mathrm{MVEC}$ cultures}

Identification of the endothelial origin was confirmed by CD31 and factor VIII immunofluorescence. As expected, due to the isolation method used, all cells were positively stained for CD31. The factor VIII distribution varied among MVEC phenotypes, as reported on bovines [30], exhibiting a sometimes perinuclear, diffuse or granular cytoplasmatic pattern while some pCL-MVECs were negative (Fig. 1C). No fluorescence was detected in the absence of a primary antibody.

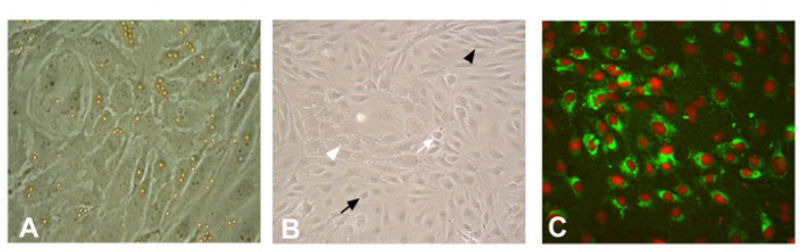

\section{Figure I}

Representative images of mid-uteal-phase porcine corpus luteum-microvascular endothelial cell (ML-P pCL-MVEC) cultures. A) pCL-MVECs after 2 days of culture with beads still attached (phase contrast microscope $\times 200$ ). B) the PCLMVEC monolayer at confluence (day 7) (phase contrast microscope $\times 100$ ). Different endothelial cell types are shown: spindle-shaped cells (black arrowhead), cobble-stone cells (white arrow), polygonal-opaque cells (black arrow), phase-dense cells (white arrowhead). C) Immunostaining for FVIII antigen (epifluorescence microscope $\times 100$ ).

StAR mRNA was not detectable in any pCL MVECs.

\section{Real time quantification of the FPr}

FPr mRNA expression was calculated as $\Delta \mathrm{C}_{\mathrm{T}}\left(\mathrm{HPRT} \mathrm{C}_{\mathrm{T}}\right.$ $\mathrm{FPr}_{\mathrm{T}}$ ). As the HPRT $\mathrm{C}_{\mathrm{T}}$ were comparable among samples, increased $\Delta \mathrm{C}_{\mathrm{T}}$ values represent an increase in FPr mRNA expression.

FPr mRNA expression levels in CL homogenates and in pCL-MVEC confluent cultures are shown in Fig. 2 and Fig. 3 , respectively.

The relative amount of FPr mRNA in luteal tissue significantly increased from EL- to ML-, reaching a maximum in the P-phase (Fig. 2A). FPr mRNA was detectable in all pCL-MVEC cultures, showing the highest expression in EL-p derived MVECs; FPr mRNA was also detectable in pAECs (Fig. 3A).

ML-p pCL-MVECs analysed at different culture times showed that FPr mRNA was highly expressed in freshly isolated ML-p pCL-MVEC then the expression was significantly reduced after an $\mathrm{ON}$ culture and reached the minimum level at confluent stage. The hormonal treatment had no regulative effect on the expression of FPr mRNA expression (Fig 4).

\section{Immunodetection of FP receptor}

Western blot analysis evidenced a band of molecular weight ( $\sim 55 \mathrm{KDa}$ ) in both CLs and endothelial cells (Fig. 2C; Fig. 3C). In luteal tissues, the FPr increased from the EL- to the ML-phase, reaching the highest level during pregnancy (P-p) (Fig. 2B). Similar levels of FPr in ML- and P-phase derived pCL-MVECs and in pAECs were observed; 


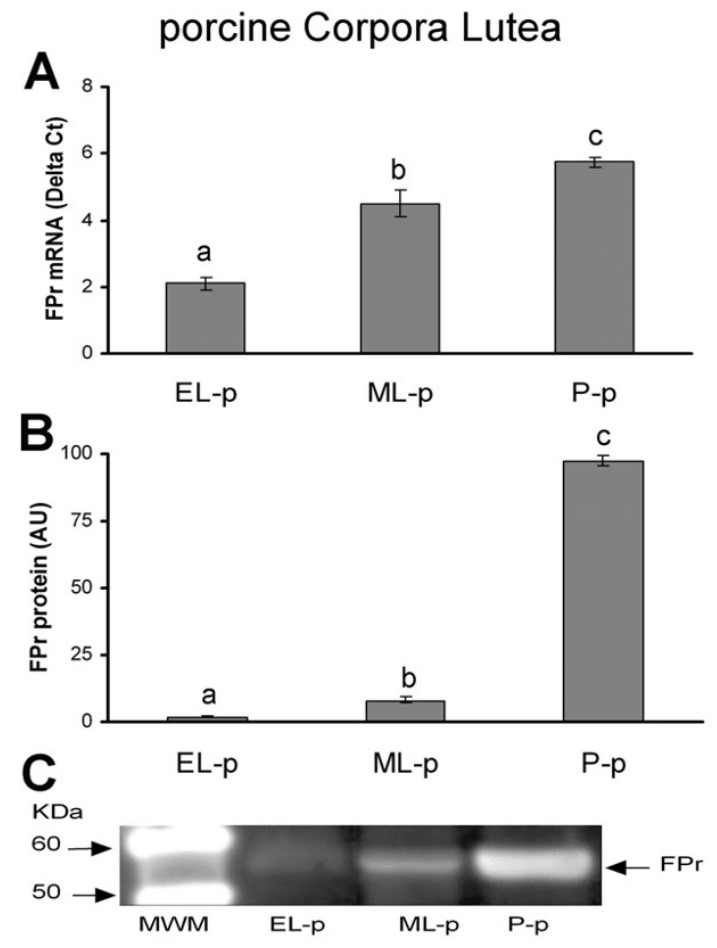

Figure 2

Presence of FPr in porcine corpora lutea ( $p C L s)$ at the earlyluteal phase (EL-p), the mid-luteal phase (ML-p) and during pregnancy (P-P). A) Relative FPr mRNA expression. The results are presented as Delta $\mathrm{Ct}\left(\right.$ HPRT $\left.C_{t}-\mathrm{FPr} \mathrm{C}_{t}\right)$. B) FPr protein content. The results are presented as $A U$ (arbitrary units). Data represent mean \pm SD. Different letters indicate statistically significant differences $(P<0.05)$. $C)$ Representative Western blotting of FPr.

EL-p-derived pCL-MVECs showed a slight but significant increase in the FPr level (Fig. 3B).

The FPr was diffusely distributed in the cytoplasm of all pCL-MVECs and in pAECs (Fig. 5A-D). Moreover, P-p pCL-MVECs showed a clear perinuclear labeling pattern (Fig. 5C). Positive staining was also observed along the plasma membrane and was more evident in non-fixed cells (Fig. 5E). No fluorescence was detected in the absence of an primary antibody.

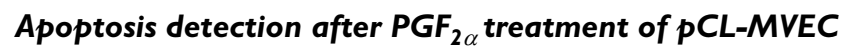
$\mathrm{PGF}_{2 \alpha}$ treatment failed to induce apoptosis in all pCLMVEC and pAEC cultures; $30 \%$ of the positive controls (LPS-treated pAECs) showed apoptotic nuclei (Fig. 6).

\section{Discussion}

In this study, we describe a reliable method for isolating and setting up primary cultures of pCL-MVECs. A positive

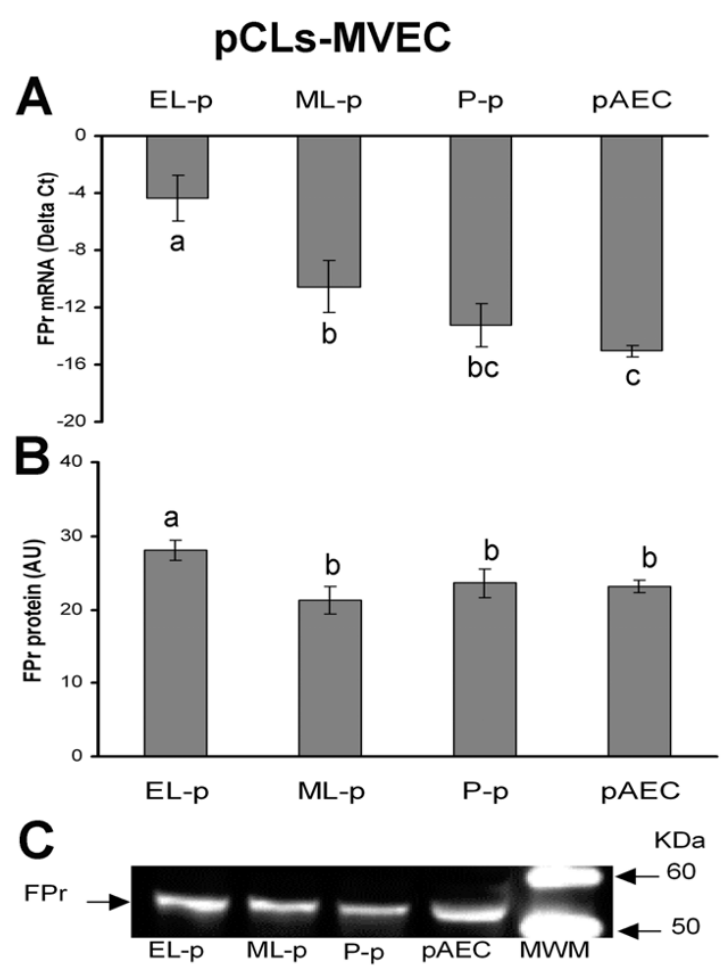

Figure 3

Presence of FPr in porcine corpora lutea-derived microvascular endothelial cells (pCL-MVECs) and porcine Aortic Endothelial Cells (pAECs). A) Relative FPr mRNA expression. The results are presented as Delta $C_{t}\left(H P R T C_{t}-F P r\right.$ $\left.C_{t}\right)$. B) FPr protein content. The results are presented as $A U$ (arbitrary units). Data represent mean \pm SD. Different letters indicate statistically significant differences $(P<0.05)$. C) Representative Western blotting of FPr.

selection with the employment of anti-CD-31-coupled magnetic beads was carried out twice. In order to support the attachment of MVECs, a basal medium optimized for bovine lung-derived MVECs supplemented with growth factors (hEGF, VEGF, hFGF, Hydrocortisone) was used until day 4 of the culture. Rare fibroblasts and parenchymal cells were observed in the culture before applying the second positive selection procedure. Cells reached confluence in a specific medium for human endothelial cells supplemented with $15 \%$ FBS. The time required to reach confluence varied for each pCL-MVEC culture; however, we observed that EL-p-derived pCL-MVECs proliferated faster than the others. This was in agreement with the high mitotic index of ECs observed during CL formation [4042]. Confluent pCL-MVEC monolayers showed a heterogeneous morphology as documented in bovine CLMVECs [23,28]. Various cell phenotypes were present with a predominance of cobble-stone-like and spindle- 


\section{pCL-MVEC ML-p}

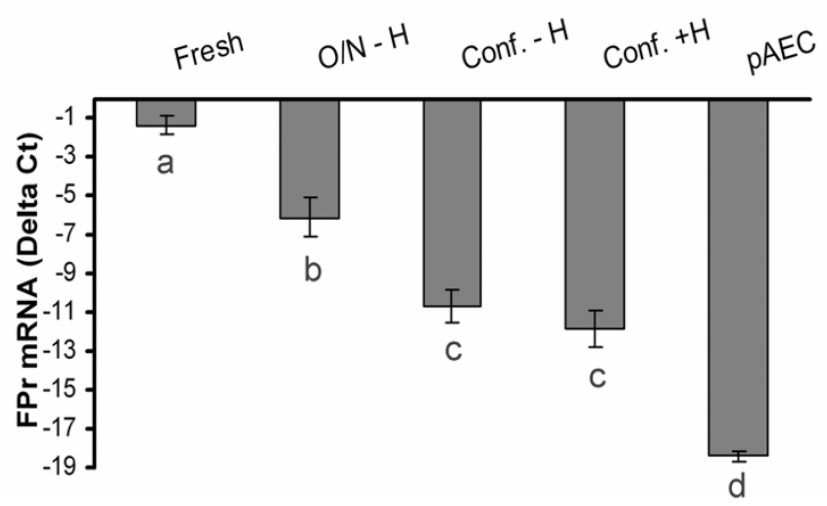

Figure 4

FPr mRNA expression in porcine corpora lutea-microvascular endothelial cells (PCL-MVECs) freshly isolated (Fresh) and cultured for different times (overnight-O/N; confluenceConf.) and in porcine Aortic Endothelial Cells (pAECs). The confluent stage of the MVECs was reached in the presence $(+)$ or absence $(-)$ of hormonal treatment $\left(\mathrm{H}=\mathrm{P}_{4}\left[10^{-6 M}\right]+\right.$ $\left.\mathrm{E}_{2}\left[10^{-8} \mathrm{M}\right]\right)$. The results are presented as Delta $\mathrm{Ct}\left(\mathrm{HPRT} \mathrm{C}_{t}\right.$ - FPr $C_{t}$ ). The data represent mean \pm SD. Different letters indicate statistically significant differences $(P<0.05)$.
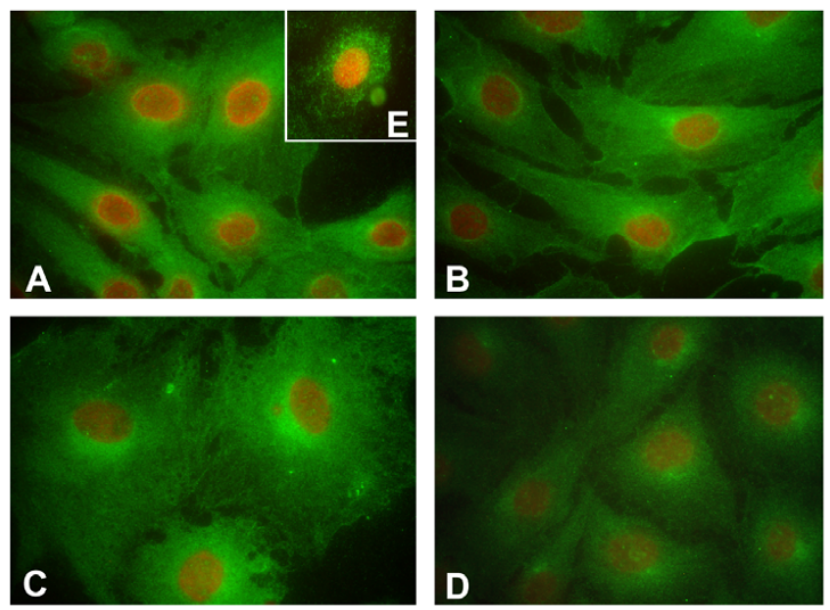

\section{Figure 5}

Representative FPr immunofluorescent staining on porcine corpus luteum-microvascular endothelial cells ( $P C L-M V E C s$ ) isolated from the early luteal phase (EL-P) (A), the mid-luteal phase $(M L-P)(B)$ and during pregnancy $(P-P)(C)(\times 400)$. D) porcine Aortic Endothelial Cell (pAEC) culture (x400). Representative immunostaining of the FPr on non-fixed EL-P PCL-MVECs is shown (E).
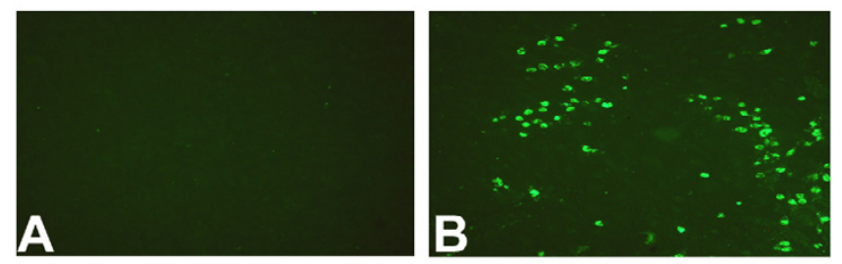

\section{Figure 6}

Effect of $\mathrm{PGF}_{2 \alpha}$ treatment on apoptosis induction in porcine corpus luteum-microvascular endothelial cells ( $P C L-M V E C s)$. A) Representative images of a TUNEL assay in $\mathrm{PGF}_{2 \alpha}$-treated mid-luteal phase (ML-p) pCL-MVECs. B) Positive TUNEL control (LPS-treated pAECs) $(\times \mid 00)$.

shaped cells in all pCL-MVECs without any relationship between the morphological types and CL phases analyzed, as reported for bovines [39]. The endothelial origin of the cells was confirmed by traditional endothelial cell marker expression. Moreover, the absence of StAR mRNA in the EC cultures indicated the absence of steroidogenic cell contamination in the confluent MVEC cultures.

FPr expression in CL tissues was found in all the stages analyzed with an increasing trend from the EL- to the MLphase reaching the maximum during pregnancy, both at mRNA and protein levels in agreement with data already published for the porcine [3] and the bovine species [43]. Our study documents, for the first time, the presence of the FPr on MVECs isolated from swine corpora lutea. We observed that the degree of expression of FPr mRNA varied among the pCL-MVEC cultures in relation to the different CL phases, the highest in the EL-p, decreasing in the ML-p and reaching its lowest level in the P-phase. At the protein level, the presence of the FPr was evidenced in all EC cultures. The amount of FPr protein was very similar among the MVECs derived from ML-p and P-p CLs and pAECs, and was significantly higher on MVECs derived from EL-p CLs. Our data, showing the presence of the FPr on MVECs at early stages testify to the fact that the refractoriness in this species was not be related to the absence of the receptor and rather that other mechanisms must be considered.

The FPr expression level in freshly isolated, overnight and long-term cultured MVECs, was gradually reduced reaching its minimum value at the confluent stage, in agreement with a recent study [31] showing that ECs modify their phenotypes when removed from the microenvironment. Nevertheless, in our model, steroid supplementation $\left(\mathrm{P}_{4}\right.$ and $\left.\mathrm{E}_{2}\right)$ resembling the in vivo hormonal environment was not able to regulate FPr expression. Further studies may be required to establish if and how culture conditions may influence FPr expression as well as to investigate if the receptor is functional on pCL-MVECs. 
The FPr presence on porcine MVECs is in agreement with data obtained for bovine CLs [7] and contrast with those obtained for swine CLs in an in situ mRNA study [8], thus confirming the hypothesis that the discrepancies among these studies are related to the different techniques used.

Finally, the immunolocalization of the FPr on MVECs showed positive staining at plasma membrane level as well as a diffuse perinuclear and cytoplasmatic localization in all cultures. Perinuclear FPr immunoreactivity may be an interaction between the outer membrane of the nuclei and the endoplasmic reticulum where nascent FP protein is formed before being transported to the plasma membrane. The perinuclear staining of P-p CL-MVECs was more intense than others, suggesting an intensive synthesis/glycosilation of the receptor. All these findings are consistent with the distribution of the FPr on ECs of human ocular tissue [44] and on the rat myometrium [45] as well as other prostaglandin receptors on porcine cerebral endothelial cells [46].

In our model, $\mathrm{PGF}_{2 \alpha}$ failed to induce an apoptotic response in all pCL MVEC cultures, in agreement with other in vitro studies conducted on bovines $[30,47]$. These results contrast with in vivo experiments which indicated endothelial cell apoptosis as an early hallmark of $\mathrm{PGF}_{2 \alpha^{-}}$ induced luteal regression in many species $[5,6,48]$. Therefore, we can affirm that $\mathrm{PGF}_{2 \alpha}$ does not directly induce apoptosis of porcine MVECs in our in vitro model, but the involvement of other molecules should be investigated $[47,49,50]$.

\section{Authors' contributions}

All the authors participated in the experimental design and collected biological material. AZ, CB and TR isolated and optimized the MVEC cultures. CB and TR carried out characterization of the MVECs. AZ and LAR carried out RNA extraction and real-time RT-PCR. CB performed the Western blots. MF performed the immunostaining of the MVECs, apoptosis and statistical analysis. MLB was responsible for animal care and surgical procedures. MLB conceived and supervised the study. AZ, MF and MLB wrote the manuscript. All authors read and approved the final manuscript.

\section{Acknowledgements}

This work was supported by a MIUR-PRIN (2005) grant and by the Consorzio Interuniversitario Trapianti d'Organo (CITO). We thank M. Soflai Sohee for carrying out the $\mathrm{P}_{4}$ analyses.

\section{References}

I. Niswender GD, Juengel JL, Silva PJ, Rollyson MK, Mclntush EW: Mechanisms controlling the function and life span of the corpus luteum. Physiol Rev 2000, 80: I-29.

2. Balapure AK, Caicedo IC, Kawada K, Watt DS, Rexroad CE Jr, Fitz TA: Multiple classes of prostaglandin F2 alpha binding sites in subpopulations of ovine luteal cells. Biol Reprod 1989, 41:385-392.
3. Gadsby JE, Balapure AK, Britt JH, Fitz TA: Prostaglandin F2 alpha receptors on enzyme-dissociated pig luteal cells throughout the estrous cycle. Endocrinology 1990, I 26(2):787-795.

4. Sakamoto K, Kamimura M, Kurozumi S, Ito S: Prostaglandin F2 alpha receptor. J Lipid Media Cell Signal 1995, I 2:405-4I I.

5. Juengel JL, Wiltbank MC, Meberg BM, Niswender GD: Regulation of steady-state concentrations of messenger ribonucleic acid encoding prostaglandin F2 alpha receptor in ovine corpus luteum. Biol Reprod 1996, 54:1096-I I02.

6. Bacci ML, Barazzoni AM, Forni M, Costerbosa GL: In situ detection of apoptosis in regressing corpus luteum of pregnant sow: evidence of an early presence of DNA fragmentation. Domest Anim Endocrinol 1996, I3(4):36I-372.

7. Mamluk R, Chen D, Greber Y, Davis JS, Meidan R: Characterization of messenger ribonucleic acid expression for prostaglandin F2 alpha and luteinizing hormone receptors in various bovine luteal cell types. Biol Reprod 1998, 58:849-856.

8. Boonyaprakob U, Gadsby JE, Hedgpeth V, Routh P, Almond GW: Cloning of pig prostaglandin F2alpha FP receptor CDNA and expression of its mRNA in the corpora lutea. Reproduction 2003, I 25:53-64.

9. Hallford DM, Wettemann RP, Turman EJ, Omtvedt IT: Luteal function in gilts after prostaglandin F2alpha. J Anim Sci 1975, $4 I(6): 1706-1710$

10. Guthrie HD, Polge C: Luteal function and oestrus in gilts treated with a synthetic analogue of prostaglandin F-2alpha (ICI 79,939) at various times during the oestrous cycle. J Reprod Fertil 1976, 48:423-425.

II. Moeljono MP, Bazer FW, Thatcher WW: A study of prostaglandin F2alpha as the luteolysin in swine: I. Effect of prostaglandin F2alpha in hysterectomized gilts. Prostaglandins 1976, I I:737-743.

12. Gadsby JE, Lovdal JA, Britt JH, Fitz TA: Prostaglandin F2 alpha receptor concentrations in corpora lutea of cycling, pregnant, and pseudopregnant pigs. Biol Reprod 1993, 49:604-608.

13. Pitzel L, Jarry $H$, Wuttke $W$ : Effects and interactions of prostaglandin F2 alpha, oxytocin, and cytokines on steroidogenesis of porcine luteal cells. Endocrinology 1993, 132:75I-756.

14. Girsh E, Wang W, Mamluk R, Arditi F, Friedman A, Milvae RA, Meidan R: Regulation of endothelin-I expression in the bovine corpus luteum: elevation by prostaglandin F 2 alpha. Endocrinololgy 1996, 137:5191-5196.

15. Wuttke W, Spiess S, Knoke I, Pitzel L, Leonhardt S, Jarry H: Synergistic effects of prostaglandin F2alpha and tumor necrosis factor to induce luteolysis in the pig. Biol Reprod 1998, 58: $|3| 0-13 \mid 5$.

16. Levy N, Kobayashi S, Roth Z, Wolfenson D, Miyamoto A, Meidan R: Administration of prostaglandin $\mathrm{f}(2$ alpha) during the early bovine luteal phase does not alter the expression of ET- $I$ and of its type A receptor: a possible cause for corpus luteum refractoriness. Biol Reprod 2000, 63:377-382.

17. Wright MF, Sayre B, Keith Inskeep EK, Flores JA: Prostaglandin $F(2$ alpha) regulation of the bovine corpus luteum endothelin system during the early and midluteal phase. Biol Reprod 200I, 65:1710-1717.

18. Rone JD, Goodman AL: Heterogeneity of rabbit aortic endothelial cells in primary culture. Proc Soc Exp Biol Med 1987, 184:495-503.

19. Chi JT, Chang HY, Haraldsen G, Jahnsen FL, Troyanskaya OG, Chang DS, Wang Z, Rockson SG, van de Rijn M, Botstein D, Brown PO: Endothelial cell diversity revealed by global expression profiling. Proc Natl Acad Sci USA 2003, 16:10623-10628.

20. Kumar S, West DC, Ager A: Heterogeneity in endothelial cells from large vessels and microvessels. Differentiation 1987, 36:57-70

21. Auerbach R, Alby L, Morrissey LW, Tu M, Joseph J: Expression of organ-specific antigens on capillary endothelial cells. Microvasc Res 1985, 29:40I-4II.

22. Klagsbrun M, D'Amore PA: Regulators of angiogenesis. Annu Rev Physiol 1991, 53:217-239.

23. Spanel-Borowski K, van der Bosch J: Different phenotypes of cultured microvessel endothelial cells obtained from bovine corpus luteum. Study by light microscopy and by scanning electron microscopy (SEM). Cell Tissue Res 1990, 261:35-47. 
24. Dorovini-Zis K, Prameya R, Bowman PD: Culture and characterization of microvascular endothelial cells derived from human brain. Lab Invest 1991, 64:425-436.

25. Ley K, Gaehtgens P, Spanel-Borowski K: Differential adhesion of granulocytes to five distinct phenotypes of cultured microvascular endothelial cells. Microvascr Res 1992, 43: I I9-I33.

26. Rodgers RJ, O'Shea JD: Purification, morphology, and progesterone production and content of three cell types isolated from the corpus luteum of the sheep. Aust J Biol Sci 1982, 35:44I-455

27. Bagavandoss $\mathrm{P}$, Wilks JW: Isolation and characterization of microvascular endothelial cells from developing corpus luteum. Biol Reprod I991, 44: II32-II39.

28. Spanel-Borowski K, Fenyves A: The heteromorphology of cultured microvascular endothelial cells. Arzneimittelforschung 1994, 44:385-39|.

29. Christenson LK, Stouffer RL: Isolation and culture of microvascular endothelial cells from the primate corpus luteum. Bio Reprod 1996, 55: I397-I404.

30. Davis JS, Rueda BR, Spanel-Borowski K: Microvascular endothelia cells of the corpus luteum. Reprod Biol Endocrinol 2003, I0:I-I5.

31. Klipper E, Gilboa T, Levy N, Kisliouk T, Spanel-Borowski K, Meidan R: Characterization of endothelin-I and nitric oxide generating systems in corpus luteum-derived endothelial cells. Reproduction 2004, I 28:463-473.

32. Plend I, Neumuller C, Vollmar A, Auerbach R, Sinowatz F: Isolation and characterization of endothelial cells from different organs of fetal pigs. Anat Embryol 1996, 194:445-456.

33. Ando H, Kubin T, Schaper W, Schaper J: Cardiac microvascular endothelial cells express $\alpha$-smooth muscle actin and show low NOS III activity. Am J Physiol 1999, 276:HI755-HI768.

34. Bernardini C, Zannoni A, Turba ME, Fantinati P, Tamanini C, Bacci $M L$, Forni M: Heat shock protein 70 , heat shock protein 32 , and vascular endothelial growth factor production and their effects on lipopolysaccharide-induced apoptosis in porcine aortic endothelial cells. Cell Stress Chaperones 2005 I 0(4):340-348.

35. Ribeiro LA, Bacci ML, Seren E, Tamanini C, Forni M: Characterization and differential expression of vascular endothelial growth factor isoforms and receptors in swine corpus luteum throughout estrous cycle. Mol Reprod and Dev 2007, 74(2): $|63-17|$.

36. Tamanini C, Bono G, Cairoli F, Chiesa F: Endocrine responses induced in anestrous goats by the administration of different hormones after fluoregestone acetate treatment. Anim Reprod Sci 1985, 9:357-364.

37. Levy N, Gordin M, Mamluk R, Yanagisawa M, Smith MF, Hampton JH, Meidan $\mathrm{R}$ : Distinct cellular localization and regulation of endothelin-I and endothelin-converting enzyme-I expression in the bovine corpus luteum: implications for luteolysis. Endocrinolology 200I, I 42:5254-5260.

38. $A B I$ Prism 7700: Sequence detection system User Bullettin \#2. Relative quantification of gene expression. Applied Biosystems 1997.

39. Plendl J, Neumuller C, Sinowatz F: Differences of microvascular endothelium in the bovine corpus luteum of pregnancy and the corpus luteum of the estrous cycle. Biol Cell 1996, 87: $179-188$

40. Jablonka-Shariff A, Grazul-Bilska AT, Redmer DA, Reynolds LP: Growth and cellular proliferation of ovine corpora lutea throughout the estrous cycle. Endocrinology 1993 |33:187|-1879.

41. Zheng J, Fricke PM, Reynolds LP, Redmer DA: Evaluation of growth, cell proliferation, and cell death in bovine corpora lutea throughout the estrous cycle. Biol Reprod 1994 5 I:623-632.

42. Ricke WA, Redmer DA, Reynolds LP: Growth and cellular proliferation of pig corpora lutea throughout the oestrous cycle. J Reprod Fertil 1999, I I 7:369-377.

43. Ishii Y, Sakamoto K: Suppression of protein kinase $\mathbf{C}$ signaling by the novel isoform for bovine PGF(2alpha) receptor. Biochem Biophys Res Commun 200I, 285: I-8.

44. Schlotzer-Schrehardt U, Zenkel M, Nusing RM: Expression and localization of FP and EP prostanoid receptor subtypes in human ocular tissues. Invest Ophthalmol Vis Sci 2002, 43: $1475-1487$
45. Al-Matubsi HY, Eis AL, Brodt-Eppley J, MacPhee DJ, Lye S, Myatt L: Expression and localization of the contractile prostaglandin $F$ receptor in pregnant rat myometrium in late gestation, labor, and postpartum. Biol Reprod 2001, 65:1029-I037.

46. Bhattacharya M, Peri K, Ribeiro-da-Silva A, Almazan G, Shichi H, Hou $X$, Varma DR, Chemtob S: Localization of functional prostaglandin E2 receptors EP3 and EP4 in the nuclear envelope. J Biol Chem 1999, 28:15719-15724.

47. Gaytan F, Morales C, Garcia-Pardo L, Reymundo C, Bellido C Sanchez-Criado JE: A quantitative study of changes in the human corpus luteum microvasculature during the menstrual cycle. Biol Reprod 1999, 60:914-919.

48. Friedman A, Weiss S, Levy N, Meidan R: Role of tumor necrosis factor alpha and its type I receptor in luteal regression: induction of programmed cell death in bovine corpus luteum-derived endothelial cells. Biol Reprod 2000, 63:1905-1912.

49. Pru JK, Lynch MP, Davis JS, Rueda BR: Signaling mechanisms in tumor necrosis factor alpha-induced death of microvascular endothelial cells of the corpus luteum. Reprod Biol Endocrinol 2003, II:I-17.

50. Choudhary E, Sen A, Inskeep EK, Flores JA: Developmental sensitivity of the bovine corpus luteum to prostaglandin F2alpha (PGF2alpha) and endothelin-I (ET-I): is ET-I a mediator of the luteolytic actions of PGF2alpha or a tonic inhibitor of progesterone secretion? Biol Reprod 2005, 72:633-642.
Publish with Bio Med Central and every scientist can read your work free of charge

"BioMed Central will be the most significant development for disseminating the results of biomedical research in our lifetime. "

Sir Paul Nurse, Cancer Research UK

Your research papers will be:

- available free of charge to the entire biomedical community

- peer reviewed and published immediately upon acceptance

- cited in PubMed and archived on PubMed Central

- yours - you keep the copyright
BioMedcentral 